\title{
Modeling the links between institutional and actual globalization in the countries of the world
}

\author{
Elena D. Kopnova
}

E-mail: ekopnova@hse.ru

\section{Lilia A. Rodionova}

E-mail: 1rodionova@hse.ru

National Research University Higher School of Economics Address: 20, Myasnitskaya Street, Moscow 101000, Russia

\begin{abstract}
The paper is devoted to modeling the links between the institutional and actual level of globalization in the countries of the world. Vector models of error correction, quantile regression, and a stochastic frontier model are considered. As a measure of globalization and its components, the KOF-index of globalization system is used, which allows us to analyze individual globalization processes in the economy, social sphere and politics. According to 2020 data, we determine the dynamic relations between the actual and institutional components of globalization, and the priority of the institutional component for informational and financial globalization is revealed. The example of financial globalization shows the uneven degree of influence of the institutional component on the actual globalization, in particular, its prevailing importance for less globalized countries, indicating the alignment of the degree of internationalization in the global financial system. The degree of effectiveness of the impact of institutional measures, together with the overall level of well-being on the actual financial globalization is analyzed. It is shown that the spread across the countries of the world in the efficiency indicator is almost $70 \%$. Almost $10 \%$ of countries have a low efficiency of up to $50 \%$. One third of the countries has average efficiency $(50-75 \%)$. The share of countries with high efficiency over $75 \%$ is about $60 \%$.
\end{abstract}

Key words: KOF index of globalization; cointegration; vector error correction model; forecast errors variance decomposition; quantile regression; stochastic frontier model.

Citation: Kopnova E.D., Rodionova L.A. (2021) Modeling the links between institutional and actual globalization in the countries of the world. Business Informatics, vol. 15, no 4, pp. 61-75. DOI: 10.17323/2587-814X.2021.4.61.75 


\section{Introduction}

$\mathrm{G}^{\prime}$ lobalization is the most important factor of social progress. It is determined by the strengthening of economic, social and political interactions of countries and peoples, regardless of national borders [1]. According to some data [2], globalization is capable of raising world GDP per capita by almost a third. The integration of trade and investment flows, the convergence of markets and the development of multinational corporations characterize economic globalization. Social globalization is expressed in the development of communication technologies, international cultural centers and personal contacts. Political globalization manifests itself in the activities of organizations that, in accordance with the principles of international law, make it possible to unite the forces of the countries of the world in the fight against global problems. The positive effects of globalization include the optimization of production due to the cross-country division of labor and access to innovation [3], the diversification of financial risks with the attraction of foreign investment [4], the increase in the level of human capital development due to the development of information technology and the international education system [5]. Researchers usually identify the main problem of globalization as an increase in income inequality [6]. Among the negative effects, there are also risks to economic security [7], violation of human rights [8] and loss of ethnic identity [9].

To measure globalization, index systems reflecting its structure are used [10]. The most popular of them is the system of the KOF-index of globalization from the Swiss Economic Institute $^{1}$. The appearance in 2018 of the latest edition of the methodology of its calculation with a radical expansion of the structure and informa- tion base significantly expanded the possibilities of studying the problems of globalization [11]. In addition to the integral indicator, the system of this index contains sub-indices of economic, social and political globalization, which in turn are divided into separate components. The economic sub-index includes sub-indices of trade and financial globalization, and the social subindex includes personal, informational, and cultural globalization. Each of these indicators is further divided into de facto and de jure categories. The indicators de facto measure the actual flows between countries (for example, the amount of imports), while de jure - their institutional capabilities (for example, import taxes). Each indicator is formed according to world official statistics since 1970, published with a delay of two years, measured on a 100 -point scale. A total of 42 variables are used. The principal component method is used for calculation, as well as the panel normalization method $^{2}$.

Most of the works on the study of globalization are devoted to analysis of its impact on the well-being of the population. The most interesting of them are the works [12-18], which use econometric tools for data analysis. However, it should be noted that these studies are limited by lack of results from studying the structure of the globalization process itself, the relationship between its individual components. This reorganization of the KOF-index of globalization in 2018 marks noticeable progress in the development of the statistical methodology for measuring globalization and expands the possibilities of its systematic analysis. Taking into account this reorganization, the authors set a goal to analyze the links between institutional and actual levels of globalization. Two main tasks were put forward. The first is to investigate the trends of dynamic relationships between de

\footnotetext{
${ }^{1}$ KOF (Konjunkturforschungsstelle) Globalisation Index: https://www.kof.ethz.ch/en/ forecasts-and-indicators/indicators/kof-globalisation-index.html

${ }^{2}$ The structure of the KOF index indicating the weights of individual indicators is given in the Appendix (Table A1)
} 
jure and de facto sub-indices. And the second is to study the degree of influence of the institutional component and the effectiveness of its application to form the actual component of globalization for the countries of the world.

\section{Methods}

\subsection{Data}

Globalization was measured by the KOFsub-indices - the de facto and de jure globalization index. All indicators were considered in the period from 1970 to $2018^{3}$. Figures $1-4$ show graphs of the analyzed time series averaged by countries of the world for the Globalization KOF-index (gl) and its components: economic (ec), social (soc) and political (pol) globalization; trade (tr) and financial (fin) globalization; personal (per), information (inf) and cultural (cul) globalization. The corresponding subindices are de facto and de jure denoted with the addition of the symbols_df, _dj.

Figure 1 shows that the acceleration of globalization in the world began in 1994. At the same time, if previously the sub-index was de facto superior to de jure, now the de jure subindex prevails. There is a noticeable divergence of trends. De jure, in general, is growing faster. Figure 2 shows that this is due to the social and political index de jure.

At the same time, Figure 2 shows that the de facto political sub-index remains noticeably smaller. Among economic sub-indices, on the contrary, the de facto sub-index is superior. The connection of the components of economic globalization is noticeable. It can be seen how the de facto sub-index follows the de jure subindex. The connection of the sub-indices of social globalization is also visible, but not so noticeable. The connection between the components of political globalization is even less noticeable.

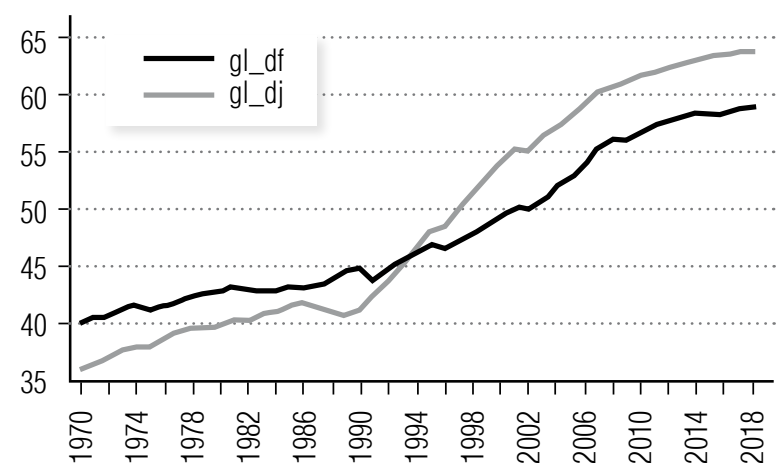

Fig. 1. Sub-indices of the de facto and de jure KOF-index of globalization

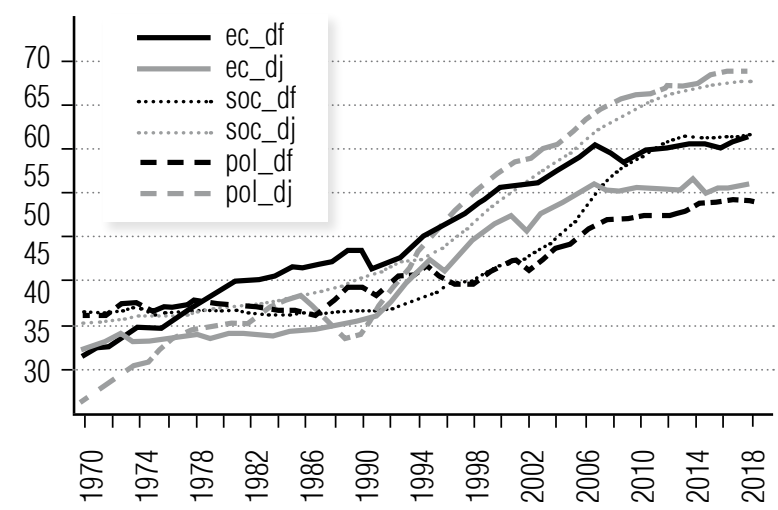

Fig. 2. De facto and de jure sub-indices of the components of the globalization KOF-index

The de facto predominance in the economic index is due to the relatively strong growth of the corresponding component of financial globalization. As part of the trade globalization index, in recent years, the values of the de facto and de jure sub-indices have been converging.

Figure 4 shows that the prevalence of the de jure sub-index in the indicator of social globalization is achieved at the expense of all components. However, a strong acceleration is noticeable for the dynamics of the de facto information globalization index in recent years. At the same time, the relationship of this index with the de jure index is visible. The cultural component of globalization is characterized by a relatively low value of the de facto sub-index.

\footnotetext{
${ }^{3}$ https://kof.ethz.ch/en/forecasts-and-indicators/indicators/kof-globalisation-index.html
} 


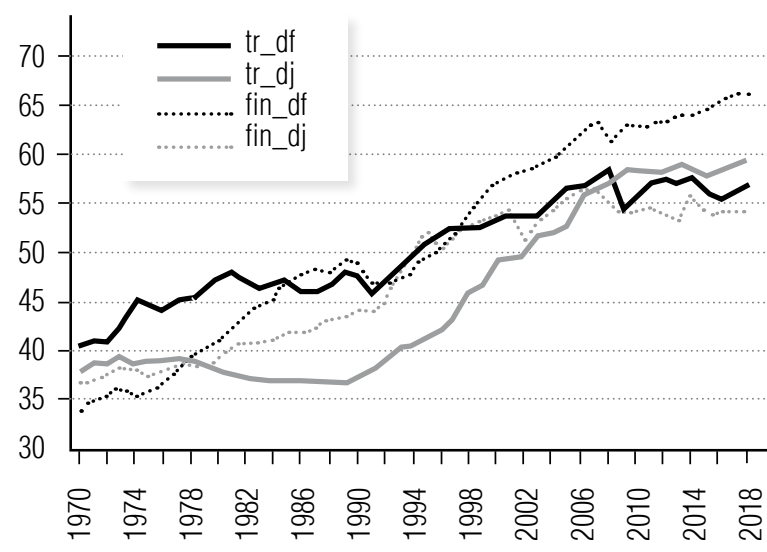

Fig. 3. De facto and de jure sub-indices of the components of the economic sub-index of the KOF-index of globalization

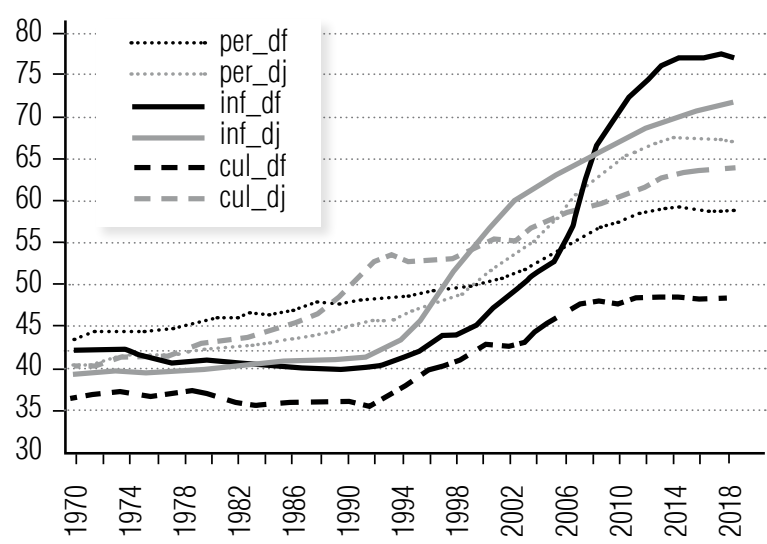

Fig. 4. Sub-indices of de facto and de jure components of the social sub-index of the KOF-index of globalization

Figure 5 shows the values of the de jure (abscissa axis) and de facto (ordinate axis) subindices of the KOF-index of globalization at the time of 2018 for 196 countries of the world. It can be seen from the figure that the sub-indices are strongly correlated. The sample value of the paired coefficient of correlation was 0.87 .

Additionally, when analyzing the spatial sample at the time of 2018, the income index was used, obtained on the basis of the logarithm of gross national income (GNI) per capita at purchasing power parity (PPP) in 2017 prices in US dollars ${ }^{4}$ and measured on a 100 -point scale. The indicator was calculated as the ratio of the logarithm of the GNI growth index to the logarithm of its maximum value ${ }^{5}$. The minimum value of GNI was assumed to be equal to $\$ 100$, as the minimum fixed in official statistics. The maximum value was set at $\$ 75,000$ in accordance with the phenomenon of the immutability of the level of well-being for countries with a higher level of GNI [19]. The Appendix contains a list of countries used in the analysis for which the index values are available. Figure 5 shows its values for these countries at the time of 2018. The figure shows that the spread of values is quite large and amounts to almost $70 \%$, which indicates a high differentiation of well-being in the countries of the world.

\subsection{Procedures}

The methodology for the study of dynamic relationships was based on the idea of cointegration analysis of random processes using the Vector Error Correction Model (VECM) [20]. Nine models of the relationship between the de facto and de jure sub-indices were constructed for the KOF-index of globalization and its components.

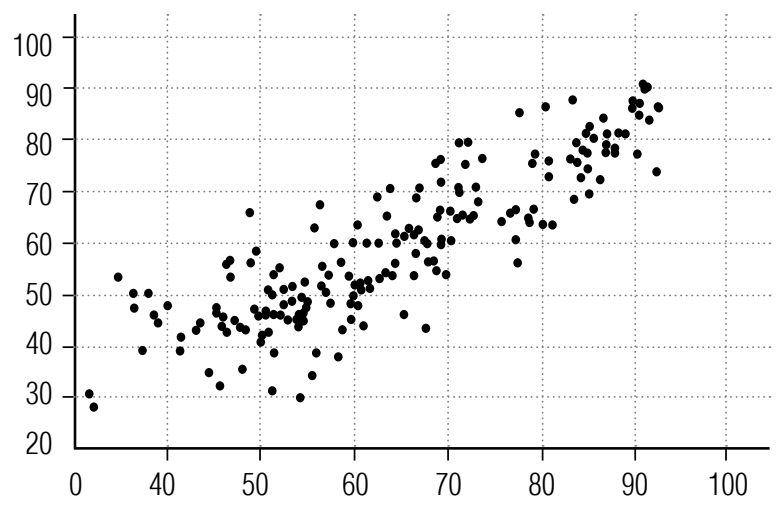

Fig. 5. De jure and de facto sub-indices of globalization 2018 for the countries of the world

\footnotetext{
${ }^{4}$ https://data.worldbank.org/indicator/NY.GNP.PCAP.PP.KD?view= chart

${ }^{5}$ Income index $=\ln \left(\mathrm{GNI} / \mathrm{GNI}_{\min }\right) / \ln \left(\mathrm{GNI}_{\max } / \mathrm{GNI}_{\min }\right) \times 100$
} 


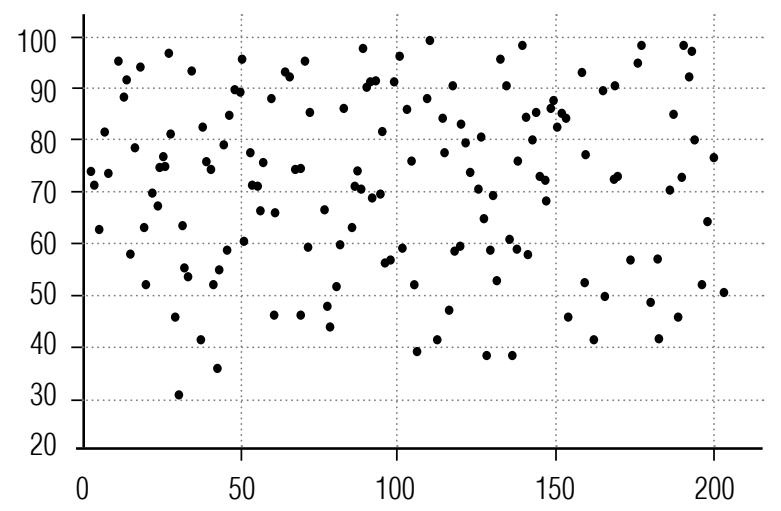

Fig. 6. Income index in the countries of the world, 2018

The general form of the model:

$$
\begin{gathered}
\Delta \boldsymbol{X}_{t}=\boldsymbol{\mu}_{t}+\boldsymbol{\alpha} \boldsymbol{\beta}^{\prime} \boldsymbol{X}_{t-1}+\sum_{j=1}^{p} \boldsymbol{\Gamma}_{j} \boldsymbol{X}_{t-j}+\boldsymbol{U}_{t}, \\
t=1,2, \ldots, T . \\
\Delta \boldsymbol{X}_{t}=\boldsymbol{X}_{t}-\boldsymbol{X}_{t-1}, \boldsymbol{\alpha}=\left\|\alpha_{i j}\right\|_{k \times r}, \boldsymbol{\beta}=\left\|\beta_{i j}\right\|_{k \times r}, \\
\boldsymbol{\Gamma}_{j}=\left\|\gamma_{i j}\right\|_{k \times k}, k=2, \\
\boldsymbol{U} \sim N\left(\mathbf{0}_{1} \boldsymbol{I}_{T} \otimes \boldsymbol{\Sigma}_{u}\right), \boldsymbol{U}=\left(U_{1}, \ldots, U_{T}\right), \\
\boldsymbol{\Sigma}_{u}=\left\|\sigma_{i j}\right\|_{k \times k}, \operatorname{cov}\left[U_{i t}, U_{j s}\right]= \begin{cases}\sigma_{i j}, & t=s \\
0, & t \neq s\end{cases}
\end{gathered}
$$

where the components of the vector $\boldsymbol{X}_{t}$ are the processes analyzed in the work; the vector $\boldsymbol{\mu}_{t}$ contains deterministic components for each of these processes: a trend and a constant; $r-$ cointegration rank; $\boldsymbol{U}_{t}$ - errors vector.

For each time series, tests were applied for the presence of a single root of the characteristic equation of the corresponding process in accordance with the algorithm of the Dolado procedure [21]. ADF (Augmented Dickey-Fuller) and KPSS (Kwiatkowski-Schmidt-Shin) tests [20] were used. The Johansen approach [22] was used to evaluate the parameters of the cointegration ratio and the error correction model. The optimal specification of the models was selected based on the Bayesian Information Criterion (BIC) and the model's compliance with its assumptions. The remnants of the mod- els were tested for the absence of autocorrelation and compliance with the normal distribution law (multidimensional analogues of the Breush-Godfrey and Jarque-Bera LM test). Durnik-Hansen orthogonalization [23] was used for the remnants of the VEC model.

The characteristics of long-term dynamic relationships for cointegrated processes were determined using testing of variables for weak exogeneity relative to the parameters of the error correction model. For this purpose, the statistical significance of the estimates of the components of the correction matrix $\boldsymbol{\alpha}$ was analyzed, since the insignificance of the estimate $\alpha_{i j}$ means that when the processes deviate from long-term equilibrium, the corresponding $i$-th variable is not corrected. To draw conclusions about strict exogeneity, the Toda-Yamamoto approach [24] was used with the choice of the number of lags in the test model according to the BIC criterion. The degree of impact of the analyzed processes on each individual process was measured using the decomposition of the variance of its prediction error, in which the selected process occupied the last position in the recursive order of causality by Wold (Wold-causality) [25]. As an impact measure for each individual process, the corresponding proportion of the estimate of the variance of the forecast error, the maximum for 10 years, was considered.

To analyze the degree of influence of the institutional factors of globalization on the actual globalization, regression models were used, estimated from the prolog data of the de facto and de jure sub-indices for 2018, averaged across the countries of the world. Taking into account the heteroscedasticity of the errors of the usual regression

$$
E\left[Y_{i} \mid \boldsymbol{X}_{i}\right]=\boldsymbol{X}_{i} \boldsymbol{\beta}(i=1,2, \ldots, n)
$$

quantile regression [26] was used for quantiles corresponding to probabilities $0.25,0.5$ and 0.75 :

$$
q_{\tau}\left[Y_{i} \mid \boldsymbol{X}_{i}\right]=\boldsymbol{X}_{i} \boldsymbol{\beta}_{\tau}, P\left\{Y_{i} \leq q_{\tau}\right\}=\tau .
$$


To analyze the heterogeneity of the influence of the factors of the formation of actual financial globalization in the world, the Stochastic Frontier Model (SFM) [27] was evaluated:

$$
\begin{aligned}
& Y_{i}=\boldsymbol{X}_{i} \boldsymbol{\beta}+V_{i}-U_{i}, U_{i} \sim \operatorname{iid} N^{+}\left(0, \sigma_{u}^{2}\right), \\
& U_{i} \geq 0, \operatorname{cov}\left[U_{i}, \boldsymbol{X}_{i}\right]=0, \operatorname{cov}\left[U_{i}, V_{i}\right]=0 .
\end{aligned}
$$

Additionally, the logarithm of the income index was taken into account as a regressor. To justify the use of the model, the remnants of the usual regression were tested for the statistical significance of the asymmetry coefficient; its sign was checked. The hypothesis about the ineffective influence of factors $H_{0}: \sigma_{u}^{2}=0$ was also tested. The evaluation of the distribution of the efficiency indicator (Ef) of the factors under consideration for the countries of the world was interpreted:

$$
\begin{gathered}
E f_{i}=\left(\frac{1-\Phi\left(\sigma_{*}-\mu_{*_{i}} / \sigma_{*}\right)}{1-\Phi\left(-\mu_{*_{i}} / \sigma_{*}\right)}\right) \exp \left(-\mu_{*_{i}}+\frac{1}{2} \sigma_{*}^{2}\right), \\
\mu_{*_{i}}=\frac{-s \varepsilon_{i} \sigma_{u}^{2}}{\sigma^{2}}, \sigma_{*}=\frac{\sigma_{u} \sigma_{v}}{\sigma}, \sigma=\sqrt{\sigma_{u}^{2}+\sigma_{v}^{2}}, \\
\Phi(x)=\frac{1}{2 \pi} \int_{-\infty}^{x} \exp \left(-\frac{x^{2}}{2}\right) d x .
\end{gathered}
$$

The efficiency distribution was compared with the ranking of the de facto index.

\section{Results}

\subsection{Analysis of dynamic relationships between de jure and de facto sub-indices}

Based on the results of testing processes for stationarity (Table 1), with a probability of 0.95 , it can be argued that all the series under consideration are realizations of random processes that are stationary in the first differences.

Table 2 shows the results of testing the de facto and de jure sub-indices for cointegration. The table shows that the hypothesis of the absence of cointegration is rejected at the significance level of 0.05 for most sub-indices with the definition of one cointegration ratio for them. The presence of a long-term relationship is not evident for the global index and sub-indices of cultural and political globalization.

The results of quality control of the evaluated VEC models showed their sufficiently high validity and allowed them to be used for analysis and interpretation. In particular, the hypothesis of the absence of autocorrelation of residues up to and including the 3-rd order was not rejected at the significance level of 0.05 for all models. Table 3 shows the results of testing cointegrated sub-indices for weak exogeneity. Statistically insignificant at the level of 0.05 estimates for the short-term ratio for the de jure sub-indices of financial and information globalization indicate a weak exogeneity of these values relative to the parameters of VEC models.

Tables 4 and 5 present the results of an analysis of the short-term relationship between the de facto and de jure sub-indices. Table 4 shows that such a relationship, as well as a long-term one, is practically not manifested for the political and cultural sub-indeices. The economic subindex is characterized by the influence of the de jure sub-index on the de facto. This is especially noticeable for the financial sub-index. For trade globalization, the de facto influence on de jure prevails a little. For the sub-index of social globalization, there is a relatively weak mutual influence of the de facto and de jure sub-indices. However, for the indices of personal and information globalization, the priority influence of de jure on de facto is noticeable.

The data in Table 5 confirm the fact that there is no short-term connection between the de facto and de jure sub-indices for political and cultural globalization. For both economic and social globalization, the defining role of the de jure sub-index is manifested. For financial and information globalization, this indicator is a highly exogenous variable relative to the parameters of the VEC model. 
Table 1 .

\section{Results of the analysis of processes for stationarity}

\begin{tabular}{c|c|c|c|c|c}
\multicolumn{2}{c}{} & \multicolumn{2}{c}{ Y } & \multicolumn{2}{c}{ dY } \\
\cline { 3 - 6 } 1 & gl_df & 0.99 & 0.21 & 0.00 & 0.34 \\
\hline 2 & gl_dj & 0.42 & 0.16 & 0.03 & 0.17 \\
\hline 3 & ec_df & 0.58 & 0.08 & 0.00 & 0.17 \\
\hline 4 & ec_dj & 0.99 & 0.13 & 0.00 & 0.20 \\
\hline 5 & soc_df & 0.52 & 0.22 & 0.06 & 0.40 \\
\hline 6 & soc_dj & 0.36 & 0.21 & 0.25 & 0.40 \\
\hline 7 & pol_df & 0.62 & 0.21 & 0.00 & 0.25 \\
\hline 8 & pol_dj & 0.46 & 0.12 & 0.01 & 0.09 \\
\hline 9 & tr_df & 0.32 & 0.09 & 0.00 & 0.16 \\
\hline 10 & tr_dj & 0.19 & 0.19 & 0.15 & 0.29 \\
\hline 11 & fi_df & 0.99 & 0.06 & 0.00 & 0.09 \\
\hline 12 & fi_dj & 0.999 & 0.149 & 0.000 & 0.214 \\
\hline 13 & in_df & 0.53 & 0.22 & 0.06 & 0.44 \\
\hline 14 & in_dj & 0.10 & 0.20 & 0.22 & 0.34 \\
\hline 15 & per_df & 0.42 & 0.19 & 0.01 & 0.17 \\
\hline 16 & per_dj & 0.03 & 0.21 & 0.32 & 0.30 \\
\hline 17 & cul_df & 0.62 & 0.19 & 0.00 & 0.27 \\
\hline 18 & cul_dj & 0.09 & 0.08 & 0.00 & 0.11 \\
\hline & & & & & \\
\hline
\end{tabular}

Notes:

1. For all series it is indicated: $Y$ is the initial series, $d Y$ is the first difference.

2. For the ADF test, one-sided MacKinnon P-values are given.

3. For the KPSS test, test statistics are compared with critical values at the significance level of 0.05: 0.146 - for the initial series (taking into account the trend) and 0.463 - for the first difference (taking into account the constant).

\subsection{Analysis of the degree and heterogeneity of the influence of institutional factors on the actual globalization}

Further, using the example of the financial globalization sub-index, the results of the analysis of the degree of influence of the de jure index on the de facto for the 2018 globalization KOF-
Table 2.

Results of the analysis of processes for cointegration*

\begin{tabular}{c|c|c|c|c}
\hline Test & \multicolumn{2}{|c|}{ Trace } & \multicolumn{2}{c}{ Max-eigenvalue } \\
\hline Grade & $\mathbf{0}$ & $\mathbf{1}$ & $\mathbf{0}$ & $\mathbf{1}$ \\
\hline $\mathrm{gl}$ & 0.54 & 0.76 & 0.76 & 0.43 \\
\hline $\mathrm{ec}$ & 0.04 & 0.07 & 0.11 & 0.07 \\
\hline soc & 0.02 & 0.22 & 0.02 & 0.22 \\
\hline pol & 0.44 & 0.98 & 0.36 & 0.98 \\
\hline tr & 0.06 & 0.71 & 0.04 & 0.71 \\
\hline fin & 0.01 & 0.92 & 0.01 & 0.92 \\
\hline in & 0.03 & 0.62 & 0.02 & 0.62 \\
\hline per & 0.06 & 0.69 & 0.03 & 0.69 \\
\hline cul & 0.13 & 0.44 & 0.14 & 0.44 \\
\hline
\end{tabular}

* MacKinnon-Haug-Michelis P-values with minimum BIC value

Table 3.

Results of the analysis of sub-indices for weak exogeneity*

\begin{tabular}{c|c|c|c|c|c|c} 
& ec & soc & tr & fin & inf & per \\
df & -2.92 & -2.04 & -2.98 & -4.22 & -3.94 & -2.37 \\
\hline dj & -2.05 & -3.90 & 2.80 & -1.57 & 1.01 & -4.83 \\
\hline
\end{tabular}

* The value of T-statistics for estimating the coefficient at the remainder of the cointegration ratio in the ECM (error correction model) for the de facto (df) and de jure (dj) sub-indices is given.

index with the involvement of the income index are demonstrated. Taking into account the omissions in the data, 145 observations were used in the models. The data was used in logarithms. There was no multicollinearity problem, since the correlation coefficient between the regressors turned out to be statistically insignificant and equal to 0.03 . Table 6 shows some results of estimating the usual regression model, quantile regression with quantiles corresponding to probabilities $0.25,0.5,0.75$, and the stochastic frontier model. 
Estimates of the decomposition

Table 4.

\section{of the variance of the forecast error in VAR/VEC models, \%*}

\begin{tabular}{c|c|c|c|c|c|c|c|c|c} 
Endogenous & $\mathrm{d}(\mathrm{gl})$ & ec & soc & $\mathrm{d}(\mathrm{pol})$ & tr & fin & inf & per & $\mathrm{d}(\mathrm{cu})$ \\
\hline $\mathrm{df}$ & 14.98 & 55.81 & 27.76 & 2.15 & 24.18 & 54.50 & 44.00 & 62.01 & 10.23 \\
\hline $\mathrm{dj}$ & 4.24 & 15.12 & 29.76 & 2.58 & 29.87 & 6.83 & 15.75 & 27.85 & 3.85 \\
\hline
\end{tabular}

* The maximum value for a 10-year period is given. For each of the de facto (df) and de jure (dj) sub-indices, in accordance with the Cholesky Ordering, the proportion of variation due to a change in the alternative variable va and he is shown.

Results of the analysis of processes for causality by Granger*

Table 5.

\begin{tabular}{c|c|c|c|c|c|c|c|c|c} 
Endogenous & gl & ec & soc & pol & tr & fin & inf & per & cul \\
\hline $\mathrm{df}$ & 0.00 & 0.01 & 0.00 & 0.45 & 0.00 & 0.03 & 0.00 & 0.01 & 0.99 \\
\hline $\mathrm{dj}$ & 0.00 & 0.45 & 0.44 & 0.50 & 0.00 & 0.87 & 0.95 & 0.06 & 0.61 \\
\hline
\end{tabular}

* The P-value of $\chi^{2}$-statistics is given to test the hypothesis that each of the de facto and de jure sub-indices is not a Granger reason for an alternative de jure and de facto sub-index.

The use of quantile regression was due to the high heteroscedasticity of the remnants of the usual regression - the P-value of the $\chi^{2}$-statistics of the Breusch-Pagan test was equal to 0.000 . This is also noticeable in Figure 5. It can be seen that there are countries with a low de jure and high de facto sub-index, but with a high de jure, high de facto is determined almost unambiguously.

Table 6 shows that all models describe the direct statistically significant impact of institutional factors, together with the indicator of the state of health, on the actual globalization in the financial sector. According to estimates of conventional regression, the de facto index value changes by almost a third of a percent on average when the de jure index changes by 1 percent. A comparison of the estimates for the $\mathrm{dj}$ indicator and their graphic illustration in Figure 7 shows that for countries with a higher level of globalization, this influence is weaker than for countries with a low level.
The application of the stochastic frontier model was facilitated by a statistically significant (at the level of 0.001), rather high modulo negative value of the residual asymmetry coefficient $(-0.788)$. The relatively low BIC value compared to its value for conventional regression also supports the use of this model. The hypothesis of the absence of inefficiency of factors was rejected at the significance level of 0.05 . Figures 8 and 9 show the results of calculating the effectiveness of the factors of the formation of actual globalization in the financial sphere for 145 countries.

\section{Discussion}

The results of the calculations showed that there is both a long-term and a short-term dynamic relationship between the processes of globalization in the institutional sphere and its actual manifestation. And although it does not manifest itself at the global level, for the general index of globalization - perhaps due to its com- 
Results of evaluation of regression models*

Table 6.

\begin{tabular}{|c|c|c|c|c|c|}
\hline & \multirow{2}{*}{$\begin{array}{l}\text { Normal } \\
\text { regression }\end{array}$} & \multicolumn{3}{|c|}{ Quantile regression } & \multirow{2}{*}{$\begin{array}{c}\text { Stochastic } \\
\text { frontier model }\end{array}$} \\
\hline & & 0.25 & 0.5 & 0.75 & \\
\hline dj & $0.29^{\star \star \star}$ & $0.51^{\star \star \star}$ & $0.27^{\star \star \star}$ & $0.16^{\star \star}$ & $0.15^{\star \star}$ \\
\hline gni & $0.44^{\star \star \star}$ & $0.61^{\star \star \star}$ & $0.39^{\star \star \star}$ & $0.41^{\star \star \star}$ & $0.37^{\star \star \star}$ \\
\hline const & $1.10^{\star \star \star}$ & -0.62 & $1.03^{\star \star}$ & $1.94^{\star \star \star}$ & $2.27^{\star \star \star}$ \\
\hline Prob $F / \gamma^{2}$ & 0.00 & 0.00 & 0.00 & 0.00 & 0.00 \\
\hline $\mathrm{R}^{2} /$ Pseudo $\mathrm{R}^{2}$ & 0.38 & 0.28 & 0.24 & 0.23 & - \\
\hline $\mathrm{BIC}$ & 35.58 & - & - & - & 27.48 \\
\hline
\end{tabular}

${ }^{*}$ The statistical significance of coefficient estimates at the level of 0.01 is marked ${ }^{* *}, 0.05-{ }^{* *}, 0.1-{ }^{*}$.

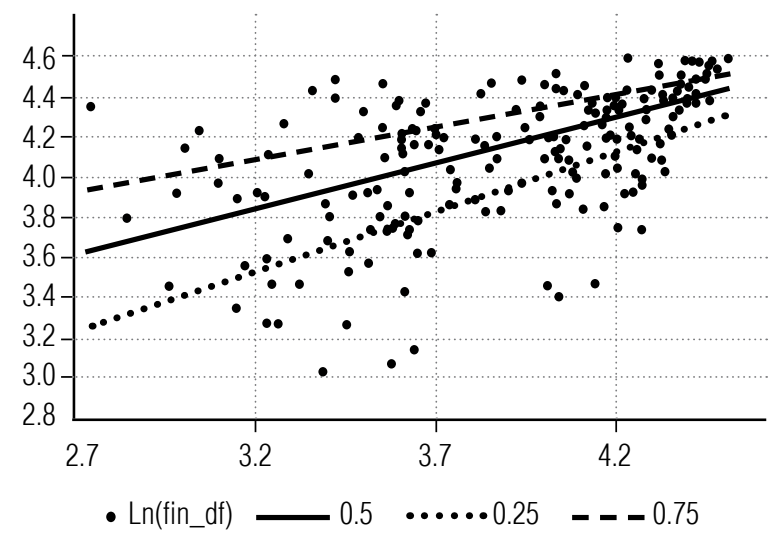

Fig. 7. Initial and model values of the logarithm of the de facto financial globalization index for quantile regression, excluding the income index

posite structure - for most of its components it is clearly traceable. The special role of institutional factors for the process of globalization has manifested itself for the financial sphere and the sphere of information technology. It turned out that their formation in these areas occurs relatively independently, without significant reliance on the results of de facto globalization in them, and they are the determining basis for actual internationalization.

The analysis of dynamic relations between de jure and de facto factors revealed the ambiguity of mutual influence for individual components of the globalization process. If economic

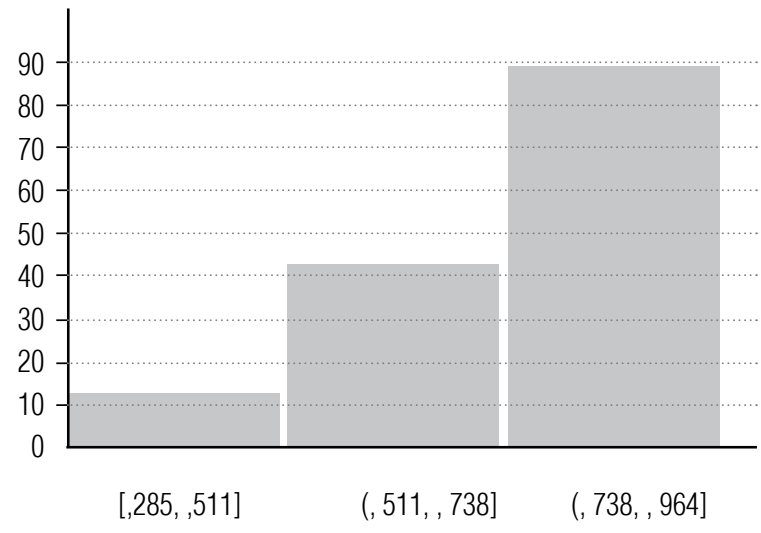

Fig. 8. Distribution of efficiency of factors of formation of actual globalization in the financial sphere

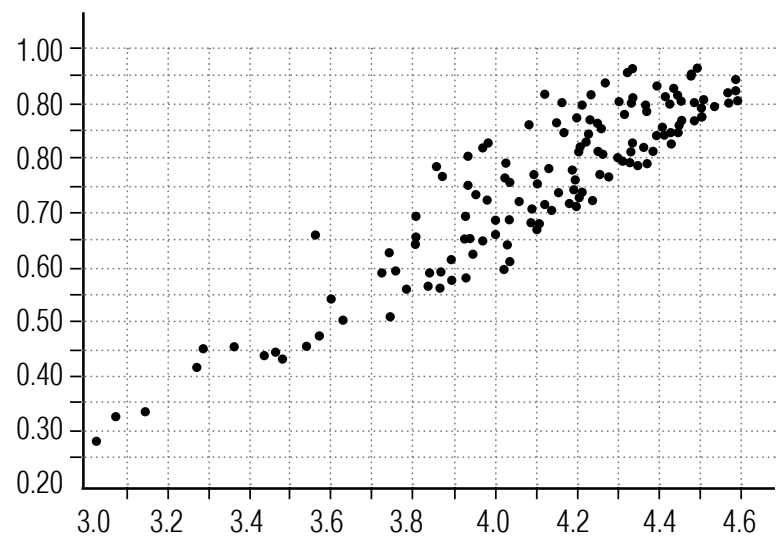

Fig. 9. The relationship of the indicator of the effectiveness of the factors

of the formation of actual globalization with the sub-index of de facto financial globalization 
globalization is characterized by a noticeable influence of institutional factors on de facto globalization, then for social globalization this apparent orientation is replaced by their mutual influence. For the process of political globalization, the connection between de jure and de facto factors has not been found, both in the long term and in the short term.

The analysis of the spatial sample according to the data of the financial globalization KOFindex at the time of 2018 indicated that in countries with a lower manifestation of actual globalization, the role of institutional factors in shaping the level of globalization is higher than in more globalized countries. Perhaps this indicates a tendency to equalize the level of financial globalization in the countries of the world.

According to the results of calculating the effectiveness of the factors of the formation of actual globalization in the financial sphere, Figure 8 shows a high heterogeneity of countries in this indicator: the spread of values occurs from 0.285 to 0.964 . Almost $10 \%(8.28 \%)$ of countries have low efficiency up to $50 \%$. These include countries such as Iran, Bangladesh, Ethiopia. Figure 7 shows that these are countries with a low level of actual financial globalization - noticeably lower than the first quantile of the logarithm of this indicator (3.937). A third of the countries (30.34\%) have average efficiency (50-75\%), for example, Turkey, Russia, Brazil. These are mainly countries with an average level of actual financial globalization that does not exceed its median (4.199). More than $60 \%(61.38 \%)$ of countries have high efficiency. Note that among the countries with high efficiency there are representatives from all groups according to the de facto index level. A complete list of countries with the valu- es of efficiency and the logarithm of the corresponding globalization index is given in the Appendix (Table A2).

\section{Conclusion}

The application of the methodology of cointegration analysis to the 2020 data of the globalization KOF-index system made it possible to determine the dynamic relationships between the actual and institutional components of globalization. It is shown that the institutional factors of globalization are the determining basis for the actual internationalization of the financial sphere and the sphere of information technology.

Modeling of the relationship between the de facto and de jure sub-indices of globalization revealed a significant heterogeneity of influence for the countries of the world. Using the example of financial globalization, the difference in the degree of influence of the institutional component on actual globalization is shown, in particular, its predominant importance for less globalized countries with a level of financial globalization less than the first quartile.

The application of the stochastic frontier model to the data of financial globalization made it possible to analyze the degree of effectiveness of the impact of institutional measures together with the overall level of well-being on the actual globalization in the financial sphere. It is shown that the level of efficiency varies in the range from 28 to 96 percent. Almost 10\% of countries have low efficiency of up to $50 \%$. One third of the countries has average efficiency $(50-75 \%)$. Thus, the share of countries with high efficiency over $75 \%$ is about $60 \%$.

\section{References}

1. Akhter S.H. (2004) Is globalization what it's cracked up to be? Economic freedom, corruption, and human development. Journal of World Business, vol. 39, no 3, pp. 283-295. DOI: 10.1016/j.jwb.2004.04.007.

2. Weiß J., Sachs A., Weinelt H. (2018) Globalization report 2018: Who benefits most from globalization. Bertelsmann Stiftung. Available at: https://ged-project.de/globalization/globalization-report-2018-whobenefits-most-from-globalization/ (accessed 01 July 2021). 
3. Tsai C. (2007) Does globalization affect human well-being? Social Indicators Research, no 81, pp. 103-126. DOI: $10.1007 / \mathrm{s} 11205-006-0017-8$.

4. Ghosh A. (2017) How does banking sector globalization affect economic growth? International Review of Economics \& Finance, no 48, pp. 83-97. DOI: 10.1016/j.iref.2016.11.011.

5. Manyika J., Lund S., Bughin J., Woetzel J., Stamenov K., Dhingra D. (2016) Digital globalization: The new era of global flows. Report. McKinsey Global Institute. Available at: https://www.mckinsey.com/ business-functions/digital-mckinsey/our-insights/digital-globalization-the-new-era-of-global-flows (accessed 01 July 2021).

6. Bergh A., Nilsson T. (2010) Do liberalization and globalization increase income inequality? European Journal of Political Economy, vol. 26, no 4, pp. 488-505. DOI: 10.1016/j.ejpoleco.2010.03.002.

7. Krylova I.A. (2016) Russia in the context of globalization: New threats. Russian Journal of Philosophical Sciences, no 4, pp. 30-44 (in Russian).

8. Dreher A., Gassebner M., Siemers L. (2012) Globalization, economic freedom, and human rights. Journal of Conflict Resolution, no 56, pp. 516-546. DOI: 10.2139/ssrn.1695446.

9. Yanitzky O.N. (2019) Challenges and risks of globalization. Seven Theses. Sociological Studies, no 1, pp. 29-39 (in Russian). DOI 10.31857/S013216250003745-2.

10. Cherkashina T.Yu. (2011) Indices of globalization: Indicators and the calculation scheme. Sociology: methodology, methods, mathematical modeling, no 33, pp. 136-165 (in Russian).

11. Gygli S., Haelg F., Potrafke N. (2019) The KOF globalisation index - revisited. Review of International Organizations, no 14, pp. 543-574. DOI: 10.1007/s11558-019-09344-2.

12. Rajan R. G., Zingales L. (2003) The great reversals: The politics of financial development in the twentieth century. Journal of Financial Economics, vol. 69, no 1, pp. 5-50.

DOI: $10.1016 / \mathrm{S} 0304-405 X(03) 00125-9$.

13. Baltagi B.H., Demetriades P.O., Law S.H. (2009) Financial development and openness: Evidence from panel data. Journal of Development Economics, vol. 89, no 2, pp. 285-296. DOI: 10.2139/ssrn.1808903.

14. Tovar-García E. (2012) Financial globalization and financial development in transition countries. Economía: Teoría y Práctica, no 36, pp. 155-178. DOI: 10.24275/ETYPUAM/NE/362012/Tovar.

15. Atif S.M., Srivastav M., Sauytbekova M., Arachchige U.K. (2012) Globalization and income inequality: A panel data analysis of 68 countries. EconStor Preprints, no 65664. ZBW - Leibniz Information Centre for Economics. Available at: http://hdl.handle.net/10419/65664 (accessed 01 July 2021).

16. Law S.H., Azman-Saini W.N.W., Tan H.B. (2014) Economic globalization and financial development in East Asia: A panel cointegration and causality analysis. Emerging Markets Finance and Trade, vol. 50, no 1, pp. 210-225. DOI: 10.2753/REE1540-496X500112.

17. Le T.H., Kim J., Lee M. (2016) Institutional quality, trade openness, and financial sector development in Asia: An empirical investigation. Emerging Markets Finance and Trade, vol. 52, no 5, pp. 1047-1059. DOI: $10.1080 / 1540496 X .2015 .1103138$.

18. Muye I.M., Muye I.Y. (2017) Testing for causality among globalization, institution and financial development: Further evidence from three economic blocs. Borsa Istanbul Review, vol. 17, no 2, pp. 117-132. DOI: 10.1016/j.bir.2016.10.001.

19. Kahneman D., Deaton A. (2014) High income improves evaluation of life but not emotional well-wbeing. Proceedings of National Academy of Sciences, vol. 107, no 38, pp. 16489-16493. DOI: $10.1073 /$ pnas.1011492107.

20. Mills T.C. (2008) The econometric modeling of financial time series. Cambridge. New York. DOI: $10.2307 / 2329254$.

21. Dolado H., Jenkinson T., Sosvilla-Rivero S. (1990) Cointegration and unit roots. Journal of Economic Surveys, no 4, pp. 243-273. 
22. Johansen S. (1988) Statistical analysis of cointegration vectors. Journal of Economic Dynamics and Control, vol. 12, no 2-3, pp. 231-254.

23. Doornik J.A., Hansen H. (2008) An omnibus test for univariate and multivariate normality. Oxford Bulletin of Economics and Statistics, no 70, pp. 927-939. DOI: 10.1111/j.1468-0084.2008.00537.x.

24. Toda H.Y., Yamamoto T. (1995) Statistical inferences in vector autoregression with possible integrated processes. Journal of Econometrics, no 66, pp. 225-250.

25. Lütkepohl H. (2007) New introduction to multiple time series analysis. New York: Springer-Verlag. DOI: $10.1017 /$ S0266466606000442.

26. Koenker R., Hallock K.F. (2021) Quantile regression. Journal of Economic Perspectives, vol. 15, no 4, pp. 143-156. DOI: $10.1257 /$ jep.15.4.143.

27. Kumbhakar S., Parmeter C., Zelenyuk V. (2017) Stochastic frontier analysis: Foundations and advances. Working Papers 2017-10, University of Miami, Department of Economics.

DOI: $10.1017 /$ CBO9781139174411.

\section{Appendix}

\section{Structure of the KOF index of globalization}

Table A1.

\begin{tabular}{|c|c|c|c|}
\hline Index & Weight & Index & Weight \\
\hline \multicolumn{3}{|c|}{ 1. Economic globalization } & 33.3 \\
\hline \multicolumn{3}{|c|}{ 1.1. Trade globalization } & 50.0 \\
\hline De facto & 50.0 & De jure & 50.0 \\
\hline Trade in goods & 38.8 & Import barriers & 26.8 \\
\hline Trade in services & 44.7 & Average tariff level & 25.6 \\
\hline \multirow[t]{2}{*}{ Variety of trading partners } & 16.5 & Taxes on trade & 24.4 \\
\hline & & Trade agreements & 23.2 \\
\hline \multicolumn{3}{|c|}{ 1.2. Financial globalization } & 50.0 \\
\hline De facto & 50.0 & De jure & 50.0 \\
\hline Foreign direct investment & 26.7 & Barriers to investment & 33.3 \\
\hline Portfolio investments & 16.5 & Capital account openness & 38.5 \\
\hline International debt & 27.6 & Investment agreements & 28.2 \\
\hline International reserves & 2.1 & & \\
\hline International income payments & 27.1 & & \\
\hline \multicolumn{3}{|c|}{ 2. Social globalization } & 33.3 \\
\hline \multicolumn{3}{|c|}{ 2.1. Personal globalization } & 33.3 \\
\hline De facto & 50.0 & De jure & 50.0 \\
\hline Phone traffic & 20.8 & Access to telephone communication & 39.9 \\
\hline Money transfers & 21.9 & Freedom of visits & 32.7 \\
\hline International tourism & 21.0 & Number of airports & 27.4 \\
\hline Migration & 17.2 & & \\
\hline International education & 19.1 & & \\
\hline
\end{tabular}




\begin{tabular}{|c|c|c|c|}
\hline \multicolumn{3}{|c|}{ 2.2. Information globalization } & 33.3 \\
\hline De facto & 50.0 & De jure & 50.0 \\
\hline Internet Usage & 37.2 & Access to television & 36.8 \\
\hline Export of high technologies & 34.5 & Internet access & 42.6 \\
\hline International patents & 28.3 & Freedom of the press & 20.6 \\
\hline \multicolumn{3}{|c|}{ 2.3. Cultural globalization } & 33.3 \\
\hline De facto & 50.0 & De jure & 50.0 \\
\hline Trade in cultural goods & 28.1 & Gender equality & 24.7 \\
\hline Exchange of services & 24.6 & Human capital & 41.4 \\
\hline International trademarks & 9.7 & Civil liberties & 33.9 \\
\hline Number of McDonalds & 21.6 & & \\
\hline Number of IKEA stores & 16.0 & & \\
\hline \multicolumn{3}{|c|}{ 3. Political globalization } & 33.3 \\
\hline De facto & 50.0 & De jure & 50.0 \\
\hline Embassies in the country & 36.5 & Membership in organizations & 36.2 \\
\hline Participation in UN missions & 25.7 & International agreements & 33.4 \\
\hline Public organizations & 37.8 & Variety of partners & 30.4 \\
\hline
\end{tabular}

\section{The effectiveness of the formation of financial globalization in the countries of the world and the logarithm of the corresponding de facto globalization sub-index ${ }^{*}$}

\begin{tabular}{|c|c|c|c|c|c|c|c|}
\hline No & country & ef & In_d & No & country & ef & In_d \\
\hline 1 & Iran. Islamic Republic & 0.28 & 3.030 & 17 & China & 0.56 & 3.835 \\
\hline 2 & Comoros & 0.33 & 3.075 & 18 & Turkey & 0.58 & 3.896 \\
\hline 3 & Bangladesh & 0.33 & 3.147 & 19 & Dominican Republic & 0.58 & 3.930 \\
\hline 4 & Ethiopia & 0.42 & 3.271 & 20 & Bolivia & 0.59 & 3.839 \\
\hline 5 & Kenya & 0.43 & 3.479 & 21 & Cameroon & 0.59 & 3.722 \\
\hline 6 & Pakistan & 0.44 & 3.437 & 22 & Gabon & 0.59 & 3.866 \\
\hline 7 & Haiti & 0.44 & 3.461 & 23 & Rwanda & 0.59 & 3.754 \\
\hline 8 & Chad & 0.45 & 3.284 & 24 & Korea. Rep & 0.59 & 4.020 \\
\hline 9 & Nepal & 0.45 & 3.363 & 25 & Romania & 0.61 & 4.033 \\
\hline 10 & Algeria & 0.46 & 3.532 & 26 & Ecuador & 0.61 & 3.896 \\
\hline 11 & Iraq & 0.47 & 3.573 & 27 & Indonesia & 0.62 & 3.943 \\
\hline 12 & India & 0.5 & 3.624 & 28 & Tanzania & 0.63 & 3.738 \\
\hline 13 & Guatemala & 0.51 & 3.744 & 29 & Botswana & 0.64 & 4.027 \\
\hline 14 & Myanmar & 0.54 & 3.600 & 30 & Egypt. Arab Republic & 0.65 & 3.971 \\
\hline 15 & Sri Lanka & 0.56 & 3.783 & 31 & Bhutan & 0.65 & 3.806 \\
\hline 16 & Paraguay & 0.56 & 3.866 & 32 & Morocco & 0.65 & 3.933 \\
\hline
\end{tabular}




\begin{tabular}{|c|c|c|c|c|c|c|c|}
\hline No & country & ef & In_d & No & country & ef & In_d \\
\hline 33 & Nigeria & 0.65 & 3.924 & 73 & United States & 0.79 & 4.371 \\
\hline 34 & Brazil & 0.65 & 3.938 & 74 & New Zealand & 0.79 & 4.330 \\
\hline 35 & Benin & 0.65 & 3.806 & 75 & Chile & 0.79 & 4.310 \\
\hline 36 & Burundi & 0.66 & 3.559 & 76 & Greece & 0.8 & 4.303 \\
\hline 37 & Philippines & 0.66 & 4.003 & 77 & Madagascar & 0.8 & 3.937 \\
\hline 38 & Mexico & 0.67 & 4.104 & 78 & Serbia & 0.8 & 4.261 \\
\hline 39 & Argentina & 0.68 & 4.108 & 79 & Armenia & 0.81 & 4.256 \\
\hline 40 & Peru & 0.68 & 4.089 & 80 & Jordan & 0.81 & 4.250 \\
\hline 41 & Sudan & 0.69 & 3.999 & 81 & Czech Republic & 0.81 & 4.381 \\
\hline 42 & El Salvador & 0.69 & 4.031 & 82 & Slovenia & 0.81 & 4.333 \\
\hline 43 & Mali & 0.69 & 3.807 & 83 & Nicaragua & 0.81 & 4.205 \\
\hline 44 & Uganda & 0.69 & 3.926 & 84 & Italy & 0.82 & 4.360 \\
\hline 45 & Russian Federation & 0.7 & 4.139 & 85 & Niger & 0.82 & 3.971 \\
\hline 46 & Belarus & 0.71 & 4.090 & 86 & Vietnam & 0.82 & 4.205 \\
\hline 47 & Maldives & 0.71 & 4.124 & 87 & Malaysia & 0.82 & 4.336 \\
\hline 48 & Poland & 0.72 & 4.199 & 88 & United Arab Emirates & 0.83 & 4.432 \\
\hline 49 & Costa Rica & 0.72 & 4.179 & 89 & Solomon Islands & 0.83 & 3.984 \\
\hline 50 & Djibouti & 0.72 & 4.061 & 90 & South Africa & 0.83 & 4.220 \\
\hline 51 & Gambia & 0.72 & 3.976 & 91 & Moldova & 0.84 & 4.224 \\
\hline 52 & Israel & 0.72 & 4.237 & 92 & Estonia & 0.84 & 4.416 \\
\hline 53 & Saudi Arabia & 0.73 & 4.206 & 93 & Panama & 0.84 & 4.400 \\
\hline 54 & Zimbabwe & 0.73 & 3.948 & 94 & Latvia & 0.84 & 4.397 \\
\hline 55 & Albania & 0.74 & 4.152 & 95 & Honduras & 0.84 & 4.164 \\
\hline 56 & Uruguay & 0.74 & 4.216 & 96 & Germany & 0.85 & 4.446 \\
\hline 57 & Oman & 0.74 & 4.211 & 97 & Spain & 0.85 & 4.429 \\
\hline 58 & Bulgaria & 0.74 & 4.200 & 98 & Hungary & 0.85 & 4.411 \\
\hline 59 & Guinea & 0.75 & 3.934 & 99 & Canada & 0.86 & 4.450 \\
\hline 60 & Cote d'Ivoire & 0.75 & 4.035 & 100 & Equatorial Guinea & 0.86 & 4.253 \\
\hline 61 & Bosnia and Herzegovina & 0.76 & 4.102 & 101 & Namibia & 0.86 & 4.248 \\
\hline 62 & North Macedonia & 0.76 & 4.198 & 102 & Liberia & 0.86 & 4.089 \\
\hline 63 & Ghana & 0.76 & 4.027 & 103 & Congo & 0.86 & 4.15 \\
\hline 64 & Lithuania & 0.77 & 4.282 & 104 & Eswatini & 0.87 & 4.232 \\
\hline 65 & Sierra Leone & 0.77 & 3.871 & 105 & Austria & 0.87 & 4.479 \\
\hline 66 & Kyrgyz Republic & 0.77 & 4.095 & 106 & Portugal & 0.87 & 4.456 \\
\hline 67 & Croatia & 0.77 & 4.255 & 107 & Vanuatu & 0.87 & 4.199 \\
\hline 68 & Colombia & 0.78 & 4.189 & 108 & France & 0.87 & 4.483 \\
\hline 69 & Tunisia & 0.78 & 4.130 & 109 & Finland & 0.87 & 4.491 \\
\hline 70 & Congo. Dem. Republic & 0.78 & 3.859 & 110 & Denmark & 0.87 & 4.499 \\
\hline 71 & Mauritania & 0.79 & 4.027 & 111 & Cabo Verde & 0.88 & 4.315 \\
\hline 72 & Japan & 0.79 & 4.343 & 112 & Sweden & 0.88 & 4.508 \\
\hline
\end{tabular}




\begin{tabular}{|c|c|c|c|}
\hline No & country & ef & In_d \\
\hline 113 & Norway & 0.88 & 4.506 \\
\hline 114 & Bahrain & 0.89 & 4.507 \\
\hline 115 & Belgium & 0.89 & 4.533 \\
\hline 116 & Jamaica & 0.89 & 4.369 \\
\hline 117 & United Kingdom & 0.89 & 4.533 \\
\hline 118 & Kazakhstan & 0.89 & 4.369 \\
\hline 119 & Senegal & 0.89 & 4.493 \\
\hline 120 & Georgia & 0.89 & 3.274 \\
\hline 121 & Switzerland & 0.9 & 4.493 \\
\hline 122 & Burkina Faso & 0.9 & 3.274 \\
\hline 123 & Brunei Darussalam & 0.9 & 4.493 \\
\hline 124 & Belize & 0.9 & 3.274 \\
\hline 125 & Luxembourg & 0.9 & 4.493 \\
\hline 126 & Netherlands & 0.9 & 3.274 \\
\hline 127 & Kiribati & 0.9 & 4.493 \\
\hline 128 & Kuwait & 0.91 & 3.274 \\
\hline 129 & Ireland & 0.91 & 4.493 \\
\hline
\end{tabular}

\begin{tabular}{|c|c|c|c|}
\hline No & country & ef & In_d \\
\hline 130 & Montenegro & 0.91 & 3.274 \\
\hline 131 & Mongolia & 0.91 & 4.493 \\
\hline 132 & Cambodia & 0.91 & 3.274 \\
\hline 133 & Lebanon & 0.91 & 4.493 \\
\hline 134 & Guinea-Bissau & 0.91 & 3.274 \\
\hline 135 & Angola & 0.92 & 4.493 \\
\hline 136 & Cyprus & 0.92 & 3.274 \\
\hline 137 & Malta & 0.92 & 4.493 \\
\hline 138 & Bahamas & 0.92 & 3.274 \\
\hline 139 & Ukraine & 0.93 & 4.493 \\
\hline 140 & Lesotho & 0.94 & 3.274 \\
\hline 141 & Mauritius & 0.94 & 4.493 \\
\hline 142 & Marshall Islands & 0.95 & 3.274 \\
\hline 143 & Togo & 0.96 & 4.493 \\
\hline 144 & Mozambique & 0.96 & 3.274 \\
\hline 145 & Timor-Leste & 0.96 & 4.493 \\
\hline
\end{tabular}

*The quartiles of the de facto index are marked in bold

\section{About the authors}

\section{Elena D. Kopnova}

Cand. Sci. (Tech.);

Associate Professor, Department of Statistics and Data Analysis, National Research University Higher School of Economics, 11 Pokrovsky Bulvar, Moscow 109028, Russia;

E-mail: ekopnova@hse.ru

ORCID: 0000-0002-8429-141X

\section{Lilia A. Rodionova}

Cand. Sci. (Econ.);

Associate Professor, Department of Statistics and Data Analysis, National Research University Higher School of Economics, 11 Pokrovsky Bulvar, Moscow 109028, Russia;

E-mail: 1rodionova@hse.ru

ORCID: 0000-0002-0310-6359 